\title{
In vivo effects of adrenocorticotrophin on the expression of the hamster steroidogenic acute regulatory protein
}

\section{A Fleury, L Ducharme and J-G LeHoux}

Department of Biochemistry, Faculty of Medicine, University of Sherbrooke, Sherbrooke, Quebec, Canada, J1H $5 \mathrm{~N} 4$

(Requests for offprints should be addressed to J-G LeHoux)

\begin{abstract}
In this study, we report the cDNA cloning of hamster adrenal steroidogenic acute regulatory (StAR) protein and the effect of adrenocorticotrophin $(\mathrm{ACTH})$ on its expression in vivo. A hamster adrenal cDNA library was screened using an $852 \mathrm{bp}$ fragment obtained by polymerase chain reaction; this fragment corresponds to the entire coding sequence (CDS) of the hamster adrenal StAR cDNA. Ten clones of different lengths were isolated and sequenced. The longest clone was $1564 \mathrm{bp}$ and contained $34 \mathrm{bp}$ in the $5^{\prime}$-untranslated region, $852 \mathrm{bp}$ in the CDS, and $678 \mathrm{bp}$ in the $3^{\prime}$-untranslated region ( $3^{\prime}$-UTR). Two polyadenylation signal sequences were found in the $3^{\prime}$-UTR. The CDS of the ten isolated clones was identical, but six of these lacked the last 132 nucleotides in the $3^{\prime}$-UTR, thus indicating that they had used the first polyadenylation signal. The hamster StAR protein
\end{abstract}

contains 284 amino acid residues, and is 91.9\% homologous to mouse, $90 \cdot 5 \%$ to rat, $86 \cdot 4 \%$ to human, $85 \%$ to porcine, and $82.5 \%$ to bovine StAR protein. Southern blot analysis indicated the presence of only one StAR gene in the hamster genome. Northern blotting analysis revealed the presence of the StAR mRNA in male and female steroidogenic tissues, namely adrenals and gonads, but not in the liver or in the kidneys of either sex. Three mRNA species of $1 \cdot 7,3 \cdot 1$ and $5 \cdot 3 \mathrm{~kb}$ were found in whole hamster adrenals. Administration of ACTH to hamsters provoked increases (two- to threefold) in the adrenal content of the StAR mRNA within $1 \mathrm{~h}$ in vivo. Western blotting analysis on adrenal mitochondria showed that the level of StAR protein was also significantly elevated (1.5-fold) $1 \mathrm{~h}$ after ACTH treatment.

Fournal of Molecular Endocrinology (1998) 21, 131-139

\section{INTRODUCTION}

Adrenal steroidogenesis involves numerous products all from one common precursor, cholesterol (LeHoux et al. 1996a). The transformation of cholesterol to pregnenolone is catalysed by the cholesterol side-chain cleavage enzyme complex $(\mathrm{P} 450 \mathrm{scc})$ located in the inner mitochondrial membrane. This reaction was long believed to be the rate-limiting step in steroidogenesis; however, it is the transfer of cholesterol from the outer to the inner mitochondrial membrane that is rate-limiting (Crivello \& Jefcoate 1980, Jefcoate et al. 1987). This transfer requires de novo synthesis of a regulatory protein which has recently been identified as the steroidogenic acute regulatory (StAR) protein (Clark et al. 1994).

The cDNA encoding the StAR protein was initially cloned from MA-10 mouse Leydig tumour cells (Clark et al. 1994). Since then, StAR cDNAs have been cloned for many animal species, namely human (Gradi et al. 1995, Sugawara et al. 1995a), ovine (Juengel et al. 1995), bovine (Hartung et al. 1995), rat (Sandhoff \& McLean 1996, Selvaraj et al. 1996, Lee et al. 1997, Miyamoto et al. 1997) and porcine (Pilon et al. 1997). The general effects of gonadotrophins (Pon \& Orme-Johnson 1986) and adrenocorticotrophin (ACTH) (Pon et al. 1986, Epstein \& Orme-Johnson 1991) on StAR protein expression have been well documented by studies with cell suspensions and cell cultures. The hormonal regulation of StAR expression in vivo has been less studied. Sandhoff \& McLean (1996) found that StAR mRNA levels in the rat ovary were regulated by pregnant mare serum gonadotrophin and human chorionic gonadotrophin (CG) treatment. Preliminary work on the regulation of the hamster adrenal StAR mRNA levels was presented 
at the Seventh Conference on the Adrenal Cortex (Fleury et al. 1996). We now report on how StAR mRNA and protein levels respond in vivo to ACTH stimulation in hamster adrenal, and on the cloning of hamster adrenal StAR cDNA. The hamster is an excellent model for such studies because, like humans, cortisol is the major glucocorticoid (LeHoux et al. 1992). Also hamster cytochrome P450 17 $\alpha$-hydroxylase can transform pregnenolone to dehydroepiandrosterone (Cloutier et al. 1997), as in human adrenals.

\section{MATERIALS AND METHODS}

\section{Materials and animals}

$\left[{ }^{32} \mathrm{P}\right] \alpha$-dCTP was purchased from Amersham Life Science Inc. (Oakville, ON, Canada), ACTH (Synacthen Depot) was obtained from Ciba Pharmaceuticals, Division of Ciba-Geigy Canada Ltd (Mississauga, ON, Canada) and $\left[{ }^{35} \mathrm{~S}\right] \mathrm{DNA}$ markers were from Amersham International plc (Little Chalfont, Bucks, UK). Adult female and male Syrian golden hamsters were purchased from Charles River Canada Inc. (St-Constant, QC, Canada). Purina rat chow and tap water were available ad libitum. Prior to and during experimentation the animals were kept in an isolated room with a controlled light-darkness cycle (lights on from 0600-1800 h).

\section{Treatment}

Five groups of four male hamsters received intramuscular (i.m.) injections of $\mathrm{ACTH}$ in the gluteal region (1 IU Synacthen Depot (equivalent to $12 \mu \mathrm{g}$ peptide) diluted in $0.3 \mathrm{ml} 0.9 \% \mathrm{NaCl} / 100 \mathrm{~g}$ body weight), at 5 -h intervals for up to $20 \mathrm{~h}$. Two groups of animals received one injection and were killed at 1 or $5 \mathrm{~h}$ after treatment; one group received 2 injections and was killed $10 \mathrm{~h}$ after the first treatment; another group received 3 injections and was killed $15 \mathrm{~h}$ after the first treatment; the last group received 5 injections and was killed $24 \mathrm{~h}$ after the first treatment. One additional group of hamsters was injected at 0 and $5 \mathrm{~h}$ and this group was killed $6 \mathrm{~h}$ after the first injection. Other groups of male hamsters were injected with $1 \mathrm{IU}$ $\mathrm{ACTH}$ and then killed at 1,3 or $5 \mathrm{~h}$ after treatment. Controls were injected with $0.9 \% \mathrm{NaCl}$ and were killed immediately after administration. For all groups, the injection schedule was organised in order to kill animals between $0800-1000 \mathrm{~h}$. Animals were killed by decapitation in accordance with the ethical standards of the institutional review committee.

\section{Cloning of hamster StAR cDNA}

Polymerase chain reaction (PCR), using Taq DNA polymerase enzyme (Pharmacia Biotech Inc. Baie d'Urfé, QC, Canada), was performed using primers based on a consensus between human and mouse StAR coding sequence (CDS). The first oligonucleotide, 5'-GGAATTCATGTTCCTCGCTA CGTTCAAGC-3', contained an EcoRI site and the start codon (ATG). The second oligonucleotide, 5'-GCTCTAGAGACACTGGGCCTCAGAGG CAGG-3', contained an XbaI site and a stop codon (TAG). From this, an 852 bp PCR product was amplified from a hamster adrenal Uni-ZAP XR custom cDNA library (Stratagene, La Jolla, CA, USA). This fragment was randomly labelled with $\left[{ }^{32} \mathrm{P}\right] \alpha$-dCTP and used to screen the same cDNA library. The screening procedures were performed as previously described (Cloutier et al. 1997). Several clones were obtained, upon which an in vivo excision of $\mathrm{pBluescript} \mathrm{SK}^{-}$from the Uni-ZAP XR bacteriophage was performed using Stratagene's ExASSIST/SOLR System (Stratagene). The isolated clones were then sequenced using Pharmacia's T7 sequencing kit (Pharmacia Biotech Inc.).

\section{Southern blotting analysis}

Genomic DNA was prepared from Syrian golden hamster kidneys. Thirty microgrammes DNA were digested with EcoRI, BamHI, HindIII, PstI, XbaI, BglII and KpnI, separated on $0 \cdot 8 \%$ agarose gel and blotted on Hybond $\mathrm{N}$ nylon membrane (Amersham International plc). The PCR fragment corresponding to the CDS of hamster StAR cDNA was radiolabelled for hybridisation. Radioactivity on the membrane was detected using an optical imager (PhosphorImager SF, Molecular Dynamics, Sunnyvale, CA, USA).

\section{RNA extraction from tissues and Northern blotting analysis}

Total RNA from hamster gonads, liver, kidneys and adrenals was extracted using the Tri-Reagent protocol (Molecular Research Center, Cincinnati, $\mathrm{OH}, \mathrm{USA})$. The poly $(\mathrm{A})^{+}$fraction was obtained using an oligo (dT)-cellulose spun column (Pharmacia Biotech Inc.). Total RNA $(15 \mu \mathrm{g})$ samples were denatured with glyoxal (Tremblay et al. 1991), and then fractionated by electrophoresis on a diethyl pyrocarbonate-treated $1 \%$ agarose gel in $0.01 \mathrm{M}$ phosphate buffer, $\mathrm{pH} 7 \cdot 0$. The fractionated RNA was transferred to positively charged nylon membranes (Boehringer Mannheim, Mannheim, 
Germany), which were then hybridised for $16 \mathrm{~h}$ at $42{ }^{\circ} \mathrm{C}$ with a ${ }^{32} \mathrm{P}$-labelled hamster adrenal StAR PCR fragment containing the entire CDS. The blots were also analysed with an $18 \mathrm{~S}$ cDNA probe for standardisation of quantities of mRNA. Autoradiograms were obtained by exposing the blots to Kodak X-Omat RP films with Hyperscreen intensifying screens (Amersham International plc, Little Chalfont, Bucks, UK). The intensity of bands on the films was determined using a LKB 2222-020 Ultroscan XL laser densitometer (Pharmacia Biotech Inc.). For some experiments, radioactivity was detected using the above mentioned optical imager.

\section{Immunoblotting}

Hamster whole adrenals were homogenised in $50 \mathrm{mM}$ Tris, $\mathrm{pH} 7 \cdot 4,0.25 \mathrm{M}$ sucrose, $5 \mathrm{mM}$ EDTA, $1 \mathrm{mM}$ phenylmethyl-sulfonylfluoride, $0.1 \mathrm{mM}$ leupeptin, $30 \mathrm{mM}$ iodoacetamide and $0.125 \mu \mathrm{M}$ aprotinin using a Potter-Elvehjem homogeniser with a loosely fitting Teflon pestle. A portion of the homogenate was centrifuged for $10 \mathrm{~min}$ at $900 \mathrm{~g}$, and the supernatant was then centrifuged for $15 \mathrm{~min}$ at $9500 \mathrm{~g}$. The mitochondrial pellet was resuspended in homogenisation buffer. Cholate and sodium dodecyl sulphate (SDS) were added to the homogenate and mitochondrial fractions to final concentrations of $1 \%$ and $0 \cdot 1 \%$ respectively. Preparations were frozen in liquid nitrogen, thawed twice and solubilised in Laemmli sample buffer (Laemmli 1970). They were passed through a 26-gauge needle, then boiled for $5 \mathrm{~min}$ and finally centrifuged at $12000 \mathbf{g}$ for $2 \mathrm{~min}$. Soluble proteins, $80 \mu \mathrm{g}$ homogenate and $50 \mu \mathrm{g}$ mitochondrial preparations were electrophoresed on $10 \%$ polyacrylamide gel in the presence of $0 \cdot 1 \%$ SDS (SDS-PAGE) and analysed by immunoblotting as previously described (LeHoux et al. 1992, 1996b) using a rabbit polyclonal anti-mouse StAR protein antibody kindly given by Dr Dale Buchanan Hales (Department of Physiology and Biophysics, University of Illinois at Chicago, Chicago, IL, USA); this antibody was raised against a GST-fusion protein from a mouse StAR cDNA fragment from bp 208-1467 (Clark et al. 1997). Immunoreactive proteins were detected using ECL light emitting reagents (Amersham International plc). The relative intensities were determined with the laser densitometer mentioned above.

\section{Cortisol determination}

Plasma cortisol was analysed by radioimmunoassay as previously described (LeHoux et al. 1992).

\section{RESULTS}

\section{Cloning of hamster StAR cDNAs and amino acid sequence alignment}

StAR cDNAs were obtained by screening a cDNA library from hamster adrenals with an 852 bp PCR fragment corresponding to the entire hamster StAR CDS. Clone 3-2 has a total length of $1564 \mathrm{bp}$, of which $852 \mathrm{bp}$ are in the open reading frame giving rise to a protein of 284 amino acids, with a predicted molecular mass of $31.5 \mathrm{kDa}$. The $5^{\prime}$-untranslated region $\left(5^{\prime}-\mathrm{UTR}\right)$ contains $34 \mathrm{bp}$, and the 3 '-untranslated region ( $3^{\prime}$-UTR) contains $678 \mathrm{bp}$ including two putative polyadenylation signals (Fig. 1). Nine other clones were sequenced and they were found to share $100 \%$ identity within the original CDS, but six of these lack the last 132 nucleotides in their $3^{\prime}$-UTR. Thus six clones utilised the first polyadenylation signal, and four utilised the second. Figure 2 shows amino acid sequence alignments between the hamster StAR protein and that of other species. The boxes indicate consensus between at least five species demonstrating a strong identity among the studied species. Proposed cleavage sites for the matrixprocessing protease and the mitochondrial intermediate-processing peptide are designated as $\mathrm{C} 1$ and $\mathrm{C} 2$ in Fig. 2. This region of the protein contains an amino acid motif that is highly conserved in presequences that undergo a twostep cleavage (Hendrick et al. 1989). The predicted molecular mass of the cleaved hamster protein is $26.3 \mathrm{kDa}$. The hydrophobicity profile (Kyte \& Doolittle 1982) obtained for the hamster StAR protein is very similar to those of the other species studied; most of the conserved regions are hydrophilic (results not shown).

\section{Genomic DNA Southern blotting}

Southern blot analysis was performed on hamster genomic DNA digested with different restriction enzymes. Results obtained suggest the presence of only one gene for StAR in the hamster genome (Fig. 3). Indeed, digestion with EcoRI, HindIII and KpnI produced single genomic fragments of $8 \cdot 2 \mathrm{~kb}, 9 \cdot 3 \mathrm{~kb}$, and $11.4 \mathrm{~kb}$ respectively, specifically hybridising with the StAR PCR fragment; this suggests that the whole CDS of hamster StAR protein was included in these fragments. BamHI, $\mathrm{XbaI}$ and BglII enzymes that do not cut in the StAR CDS produced two fragments, suggesting that these enzymes have restriction sites in intronic sequences of the StAR gene. 
AAGTCCTACAGACATCTGCGGAACATGAAAGGACTGAGACACCAAGCTGTGCTGGCCATTGGCCAGGAA SerSerTyrArgHisLeuArgAsnMe $L$ YSGIYLeuArgHisGInALaValLeuAlaIleGIYGInGIu

CTCAACAGAAGAACACTGGGAGACTCCAGCCCTGGATGGATCAGTCAGGTTCGGCGTCGGAGCTCTCTG LeuAsnArgArgThrLeuGlYAspSerSerProGlYTrpIleSerGlnValArgArgArgSerSerLeu

CTTGGTTCTCAGCTGGAAGCGGCACTCTACAGTGAGCAGGAGCTGTCCTATATCCAGCAGGGAGAGGTG LeuGlySerGlnLeuGluAlaAl aLeuTyrSerGluGlnGluLeuserTyrIleGlnGlnGlyGluVal

GCTATGCAGAAGGCCTTGAGTATCCTCAGCAACCAGGAAGGCTGGAAGAAAGAGAACCAGCAGGAAAAC AlaMetGlnLysAlaLeuSerIleLeuSerAsnGInGIuGIYTrPLYSLYsGIuAsnGInGInGluAsn

GGGGATGAGGTGCTGAGTAAAGTGGTCCCTGATGTGGGCAAGGTATTTCGGCTGGAGGTGGTGGTAGAC GlYAspGluValLeuSerLysVaIVal ProAspValGlYLYsVal PheArgLeuGluValValValAsp

CAGCCCATGGACAGACTCTATGCAGAACTTGTGGACCGCATGGAGGCAATGGGAGAGTGGAACCCAAAT GlnProMetAspArgLeuTYrAlaGluLeuValAspArgMetGluAlaMetGlyGluTrpAsnProAsn

GTCAAGGAGATCAAGGTCCTGCAAAAGATTGGGAAAGACACAGTCATCACCCATGAGCTGGCTGCAGCA ValLysGluIleLysValLeuGI nLYsIleGlyLysAspThrVal I leThrHisGluLeuAlaAlaAla

GCAGCAGGAAACCTGGTGGGACCCCGTGACTTTGTGAGCGTACGCTGTGCCAAGCGCCGAGGCTCCACC AlaAlaGlyAsnLeuValGlyProArgAspPheVal SerValArgCysAlaLysArgArgGlySerThr

TGTGTGCTGGCAGGCATAGCCACACATTTTGGGGAGATGCCTGAACAAAGCGGTGTTATCAGAGCTGAA CysValLeUAIaGlYIIEAlaThrHisPheGlyGluMetProGluGlnSerGlyValIleArgAlaGlu

CAGGGTCCCACCTGCATGGTGCTTCACCCACTGGCTGGGAGTCCCTCGAAGACTAAATTCACTTGGCTG GlnGlyProThrCysMetValLeuHis ProLeuAlaGlyserProserLysThrLys PheThrTrpLeu

CTCAGTATTGACCTCAAGGGGTGGCTGCCGAAAAGCATCATCAATCAGGTCTTATCACAAACCCAGATG LeuSerIleAspLeuLysGlYTrpLeuProLysSerIIeI leAsnGInVal LeuSerGInThrGInMet

GAGTTTGCCAACCACCTGCGCAAGCGCCTGGAGTCCAGCTCTGCCTCTGAGGCCCGGTGTtaagactgt GluPheAlaAsnHisLeUARgLYsArgLeuGIuSerserserAlaSerGluAlaArgCys

acccactacatcaacctgcatgccatcagcagcctccegcaggaagcctgcaagtctgtttcaaatctc cagttgatgactacgggaggggtagtacttatcagacactaggactgactggcgaaacatgaccatcag gaattagcaatgaggctgagcagaagagagcctcagcctctcccacaagattagctgtgaagtgggct aagagatagacatgctaacacttttatgtaggcetgtgtatgctcacctaaaaaccctactcaaaacgc aagtagttagtgtgacaagggggggtgtttaggaactgttgtcttctgagctcaaagccactgcctgaa gcagtgtgtgcacacagcaaggcttccccagggacttcagtgaccetctgttcctccataaaaggccaa gaacatcaaaccactcacaaacagaccettccagagtacactccaagttctctctaaggagaaaggaaa A

ctaaatattacgttggcttccctacttattacatcacaataaagtaccacacatgaaattcagcctat $\quad 1447$ acttgtcaagtcctatggcacagaatctgtgctgggagccacagcttcatcagagctctggatcaagac $\frac{1447}{1516}$ tgtgggttccaatttcctagttcattaaggaacaaacttcacattt

FIGURE 1. Nucleotide and deduced amino acid sequences of the StAR cDNAs isolated from a Syrian hamster adrenal library. Numbers underlined indicate nucleotide positions, those in parentheses indicate amino acid positions. The two putative polyadenylation signals 'ataaa' and 'attaaa' are doubly underlined. Six clones utilised the first polyadenylation signal and terminated at nucleotide 1432 (A). Four clones utilised the second polyadenylation signal, two terminated at nucleotide 1557 (B) and two others at nucleotide $1564(\mathrm{C})$. Both $5^{\prime}$ - and $3^{\prime}$-UTR are in lower case; the capitalised letters indicate the nucleotides of the open reading frame. The longest cDNA sequence was deposited in the GenBank database under the accession number U66490.

\section{Tissue distribution of hamster StAR mRNAs}

The tissue distribution of hamster StAR mRNAs was assessed by Northern blotting analysis (Fig. 4). Total RNA was extracted from female and male hamsters of the same age, from ovary, testis, liver, kidneys and adrenals. Poly $(\mathrm{A})^{+}$RNA was also pre- pared from adrenals. Hybridisation with a ${ }^{32} \mathrm{P}-$ labelled PCR fragment containing the entire CDS of hamster StAR protein revealed the presence of StAR mRNA in adrenal tissues and gonads of both sexes, but not in liver or kidneys, where no signals were detected even after $72 \mathrm{~h}$ of film exposure (results not shown). Two major mRNA species of $1.7 \mathrm{~kb}$ and 


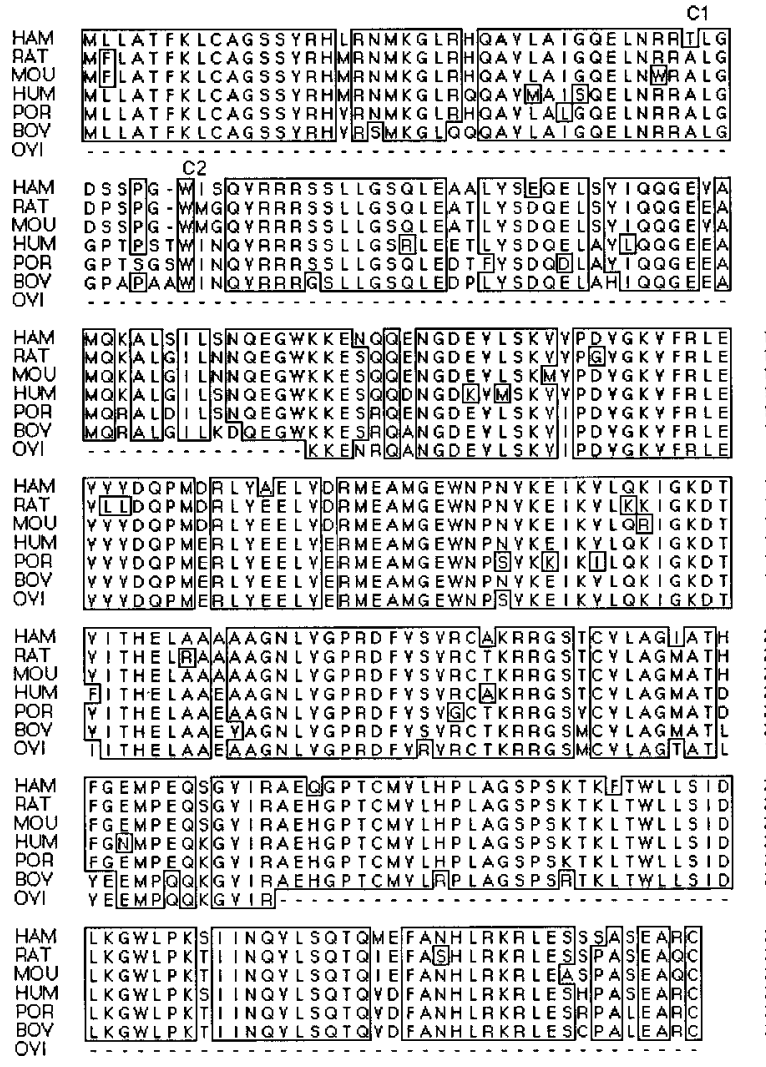

41
37
41
41
41
41
0
0
81
77
81
82
82
82
0
122
118
122
123
123
123
27
27
163
159
163
164
164
164
68
204
204
200
204
205
205
205
109
245
245
241
245
246
246
246
121
284
284
280
284
285
285
285
129
0

FIGURE 2. Comparison of the deduced amino acid sequence of the hamster (HAM) StAR protein with that of other species. The compared species were rat (RAT), mouse (MOU), human (HUM), pig (POR), bovine $(\mathrm{BOV})$ and ovine $(\mathrm{OVI})$. Boxes indicate consensus between at least five species. The ovine sequence is incomplete. For mouse and hamster, the proposed cleavage sites for the mitochondrial matrix-processing protease and the mitochondrial intermediate-processing peptide are indicated by $\mathrm{C} 1$ and $\mathrm{C} 2$ respectively.

$3 \cdot 1 \mathrm{~kb}$ were found in adrenals and gonads. Minor mRNA species of $5.3 \mathrm{~kb}$ in adrenals and $6 \mathrm{~kb}$ in gonads were also found. The $6 \mathrm{~kb}$ band was more intense in the testis than in the ovary. Hybridisation of the ${ }^{32} \mathrm{P}$-labelled PCR fragment with the adrenal poly $(\mathrm{A})^{+}$RNA indicated that the three StAR mRNA species were polyadenylated, and consequently were not pre-mRNA. Based on poly $(\mathrm{A})^{+} \mathrm{RNA}$ results, in adrenals of control hamsters, the relative abundance of $1.7 \mathrm{~kb}, 3 \cdot 1 \mathrm{~kb}$ and $5.3 \mathrm{~kb}$ StAR mRNA was $55 \%$, $42 \%$, and $3 \%$.

\section{ACTH-stimulated expression of hamster StAR mRNA in vivo}

We have studied the short term (one injection) and long term (up to five injections) effects of ACTH on

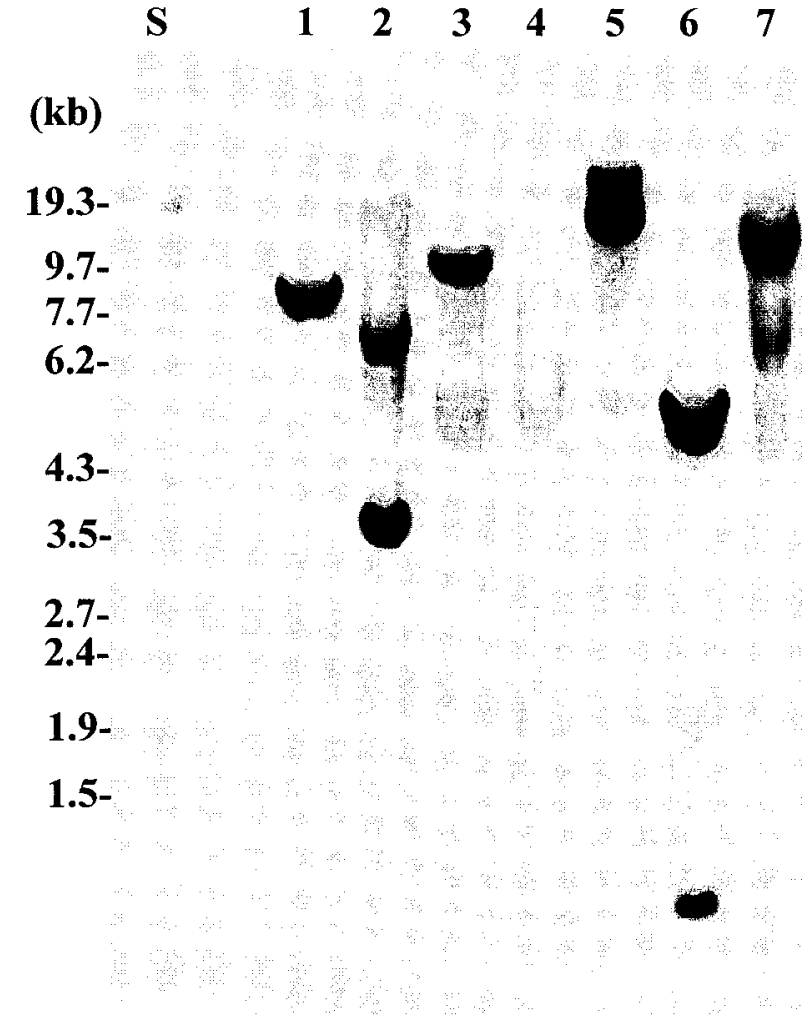

FIGURE 3. Genomic Southern blot for hamster StAR gene. Genomic DNA (30 $\mathrm{g}$ ) prepared from hamster kidney was digested with EcoRI, BamHI, HindIII, PstI, XbaI, BglII and KpnI, lanes 1 to 7 respectively. After electrophoresis and transfer on nylon membrane, digested DNA was hybridised with a hamster StAR PCR fragment corresponding to the entire CDS.

$\mathrm{S},\left[{ }^{35} \mathrm{~S}\right] \mathrm{DNA}$ markers used for estimation of the length of genomic fragments; kb, kilobases.

StAR mRNA levels. We previously reported (LeHoux et al. 1992) that one single injection of ACTH to hamsters could not sustain elevated plasma cortisol for more than $5 \mathrm{~h}$, and that serial $\mathrm{ACTH}$ injections at 5-h intervals resulted in sustained high plasma cortisol levels. Northern blotting analysis (Fig. 5) showed that the administration of ACTH to hamsters provoked an increase in the intensity of the two main StAR mRNA bands at 1.7 and $3.1 \mathrm{~kb}$ in the adrenal; indeed, within $1 \mathrm{~h}$ after ACTH administration, the level of these two mRNA bands was increased by $192 \%$ and $299 \%$ respectively. For the $1.7 \mathrm{~kb}$ band the greatest increase was observed when hamsters were sacrificed at time $5 \mathrm{~h}(291 \%)$, whereas the increase for the $3 \cdot 1 \mathrm{~kb}$ band was $293 \%$. Moreover, these increases were sustained at times 10, 15, and $24 \mathrm{~h}$. When animals were injected at times 0 and $5 \mathrm{~h}$ 


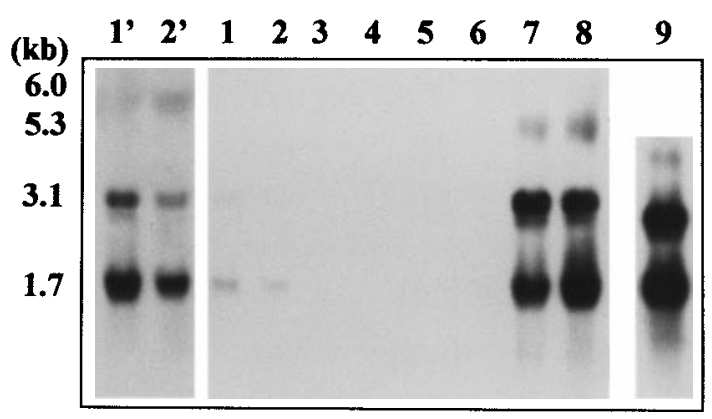

FIGURE 4. Tissue distribution of hamster StAR mRNAs. Lanes 1' and 2': $15 \mu \mathrm{g}$ total RNA from ovary and testis with a film exposure time three times longer than for lanes 1 to 9 (film exposure time is $24 \mathrm{~h}$ ). Lanes 1-8: $15 \mu \mathrm{g}$ total RNA from ovary, testis, female kidney, male kidney, female liver, male liver, female adrenal and male adrenal respectively. Lane 9: $1 \mu \mathrm{g}$ poly $(\mathrm{A})^{+} \mathrm{RNA}^{+}$ from male hamster adrenals. Electrophoresis was carried out in $1 \%$ agarose gel. The kb scale on the right hand side is for lane 9 only. $\left[{ }^{35} \mathrm{~S}\right] \mathrm{DNA}$ markers were used for estimation of the length of transcripts.

and then killed $6 \mathrm{~h}$ after the first injection, the adrenal level of StAR mRNA was further increased $(1.7 \mathrm{~kb}, \quad 412 \% ; \quad 3.1 \mathrm{~kb}, \quad 364 \%)$, compared with animals which had received only one injection at time 0 and were killed at time $5 \mathrm{~h}$. The $5 \cdot 3 \mathrm{~kb}$ band was also increased, with a peak intensity $5 \mathrm{~h}$ after ACTH administration, and decreased thereafter. Membranes were stripped and then hybridised with a ${ }^{32} \mathrm{P}-$ labelled $18 \mathrm{~S}$ cDNA probe (results not shown) and results obtained were used to normalise the relative quantity of RNA between wells.

\section{Western analysis on hamster adrenal under in vivo ACTH treatment}

Western blotting analysis on hamster adrenal mitochondrial preparations showed the presence of three immunoreactive protein bands of about 32,30 and $29 \mathrm{kDa}$. The levels of the 30 and $32 \mathrm{kDa}$ bands were already significantly elevated $1 \mathrm{~h}$ after ACTH treatment, with increases of $147 \pm 13 \%$ and $135 \pm 10 \%$ (means \pm s.E.M., $n=3, P<0.05$ ) respectively, and remained elevated at $5 \mathrm{~h}$; the apparent increase of the $29 \mathrm{kDa}$ band was not statistically significant (Fig. 6). Similar results were obtained with homogenate preparations (results not shown). Hamster plasma cortisol levels in nmol/l (means \pm S.E.M., $n=3)$ were $8 \cdot 3 \pm 1 \cdot 3$ for controls and $127 \pm 30$ $(P=0 \cdot 017), \quad 88 \pm 24 \quad(P=0 \cdot 028)$, and $42 \pm 34$ (not significant) at times 1,3 and $5 \mathrm{~h}$ after ACTH treatment.

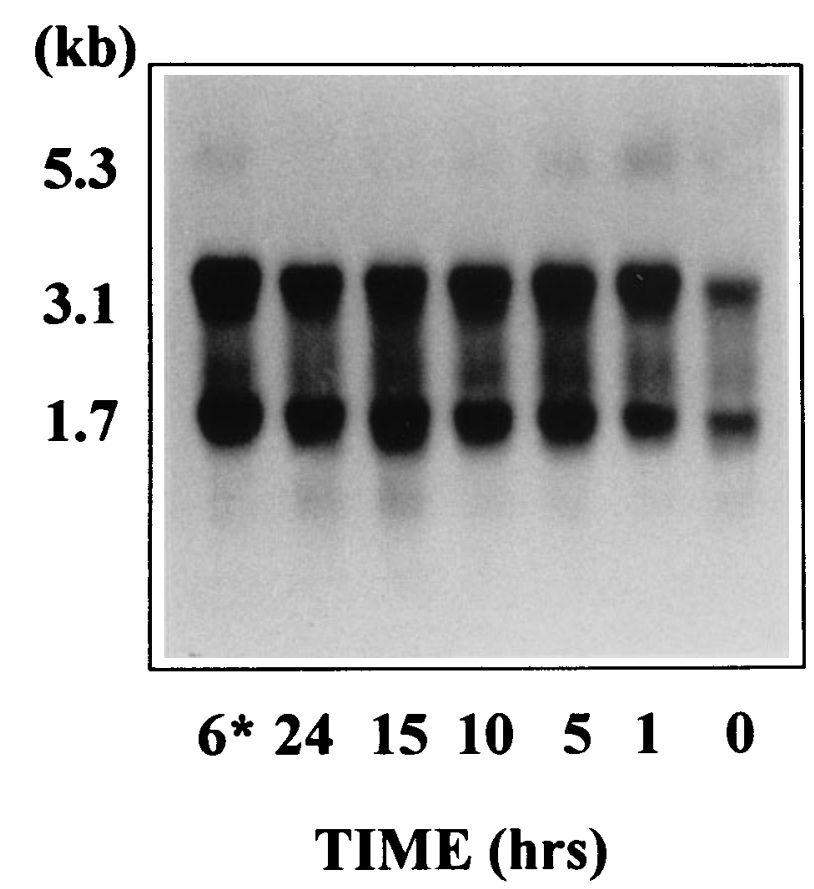

FIGURE 5. The effects of ACTH on the level of hamster adrenal StAR mRNA. Groups of male hamsters received one, two, three or five i.m. injections of ACTH at 5-h intervals, as described in Materials and Methods. These animals were killed at $1,5,10,15$ or $24 \mathrm{~h}$ after the first injection. One additional group of hamsters $\left(6^{*}\right)$ was injected at 0 and $5 \mathrm{~h}$ and this group was killed $6 \mathrm{~h}$ after the first injection. Controls were injected with $0.9 \%$ $\mathrm{NaCl}$. Electrophoresis was carried out in 1\% agarose gel. $\left[{ }^{35} \mathrm{~S}\right]$ DNA markers were used for estimation of the length of transcripts. Film exposure time was $72 \mathrm{~h}$.

\section{(kDa)}

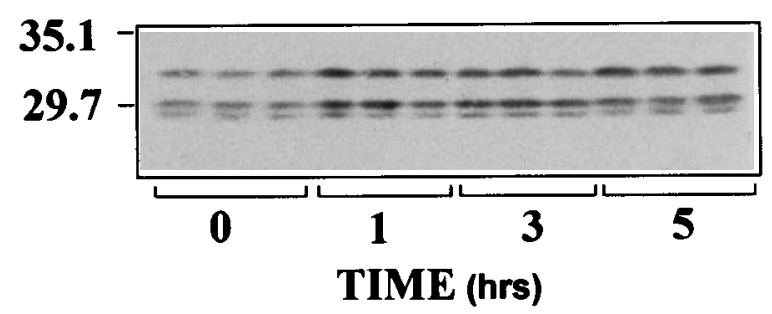

FIGURE 6. Western blotting analyses on hamster adrenal mitochondrial preparations. Groups of three male hamsters were injected i.m. with $1 \mathrm{IU}$ ACTH; they were killed 1,3 or $5 \mathrm{~h}$ after treatment. Controls were injected with $0.9 \% \mathrm{NaCl}$. Analyses were performed on $50 \mu \mathrm{g}$ mitochondrial protein on SDS-PAGE.

\section{DISCUSSION}

The deduced amino acid sequence of the hamster StAR protein is composed of 284 residues and thus falls in a distinct sub-group with the mouse and the 
rat. In comparison, the deduced amino acid sequence of the human, porcine and bovine StAR protein possesses 285 , one more amino acid than that of rodents (Fig. 2). The hamster StAR protein sequence is highly homologous with that of the mouse $(91.9 \%)$ and only slightly less with that of the rat, human, porcine, and bovine proteins. The hamster StAR protein shares 100\% identity with the putative mitochondrial signal sequence cleavage site described for the mouse sequence (Stocco \& Clark 1996). This sequence follows the consensus motif for two cleavages (Hendrick et al. 1989), whereas only one cleavage is predicted for sequences of other species (Fig. 2). Furthermore, the primary structure of the hamster StAR protein is very similar to that of the mouse for the first 25 residues $(23 / 25)$ at the amino terminus and the predicted secondary structure is an amphipathic $\alpha$ helix (Clark et al. 1994), a characteristic consistent with mitochondrial targeting sequences.

The hamster StAR protein possesses many consensus motifs for different putative phosphorylation sites. Many putative phosphorylation sites are conserved between species, which strongly suggests that they could be the sites of those post-translational modifications necessary for the transfer of cholesterol to P450 scc in the mitochondria. In agreement with this, Arakane et al. (1997) reported that phosphorylation of serine 195 on the human StAR protein increases the biological activity of StAR which accounts, in part, for the immediate effects of cAMP on steroid production. Moreover, it has been shown that phosphoproteins were generated following ACTH (Krueger \& Orme-Johnson 1983, Pon et al. 1986) or cAMP stimulation of rat adrenal cells (Elliott et al. 1997).

In agreement with reports on other species, StAR mRNA was found in hamster steroidogenic tissues, namely adrenals and gonads. No StAR mRNA was found in the liver or in the kidneys by Northern analysis. In humans, a $1.6 \mathrm{~kb}$ StAR mRNA was detected in a kidney preparation (Sugawara et al. $1995 a$ ). In agreement with our preliminary report (Fleury et al. 1996), in non-stimulated hamster adrenals, two major StAR mRNA species were revealed by Northern analysis at $1.7 \mathrm{~kb}$ and $3.1 \mathrm{~kb}$, and a minor species at $5 \cdot 3 \mathrm{~kb}$ (Fig. 4). These three mRNA species were also found after chromatography of total adrenal RNA on an oligo-dT column, indicating that they were polyadenylated. After a long exposure time, a transcript of $0.65 \mathrm{~kb}$ was also observed, but this mRNA species was not stimulated by ACTH treatment (Fleury et al. 1996) and may not be related to StAR. Hartung et al. (1995) have also found a weak low molecular weight mRNA band in bovine adrenal hybridising with a bovine StAR cDNA probe, which they tentatively identified as a tissue inhibitor of metalloproteinases (TIMP-1) mRNA. The two main StAR mRNA species were also found in hamster testis and ovary with the $1.7 \mathrm{~kb}$ species predominating. In gonads, the $5.3 \mathrm{~kb}$ mRNA band was absent and after a long exposure time, a $6 \mathrm{~kb}$ species was revealed. The level of StAR mRNA in the gonads was much lower than that in the adrenals, probably due to the preparations containing fewer steroidogenic cells.

In this study we sequenced ten StAR cDNAs isolated from a hamster adrenal cDNA library. Although the CDS of these cDNA was identical, the 3 '-end differed in length and two polyadenylation signal sites were identified. These cannot explain the difference in length of mRNA species observed by Northern analysis. Various explanations have been proposed for the different lengths of StAR mRNAs in different species. For example other $3^{\prime}$-end polyadenylation sites could be present in the hamster StAR gene. In agreement with this hypothesis, Hartung et al. (1995) have cloned a bovine StAR transcript from a downstream polyadenylation site which gives rise to a long $3^{\prime}$-UTR. In the rat, the very long exon seven explains the synthesis of the $3.5 \mathrm{~kb}$ mRNA (Kim et al. 1997). Longer mRNA species could also come from alternative splicing. Indeed, Sugawara et al. (1995b) isolated and sequenced one structural human StAR gene which they predicted to be 1642 nucleotides, in agreement with the size of the primary StAR mRNA observed by Northern blotting analysis. Since the human gene spans $8 \mathrm{~kb}$ and consists of seven exons and six introns, they speculated that the larger StAR mRNA species of $4.4 \mathrm{~kb}$ and $7.5 \mathrm{~kb}$ observed in human adrenals may represent nascent transcripts of partially or alternatively spliced mRNAs.

The stimulating effect of ACTH on the production of hamster adrenal StAR mRNA was seen $1 \mathrm{~h}$ after its administration (Fig. 5), and maximal stimulation occurred within $5 \mathrm{~h}$. However, when animals were killed at $6 \mathrm{~h}, 1 \mathrm{~h}$ after the second injection, a further enhancement of the StAR mRNA levels was observed. This suggests that ACTH injection initially increases StAR mRNA levels over the first hour, and that these then fall back to lower levels but can be increased again by subsequent injection which increased circulating ACTH. Although ACTH increased the intensity of the three mRNA bands $(1 \cdot 7,3 \cdot 1$ and $5 \cdot 3 \mathrm{~kb})$, the $1 \cdot 7$ and $3.1 \mathrm{~kb}$ mRNA bands were the most affected. In agreement with our results, Kim et al. (1997) reported that in hypophysectomised rats, ACTH stimulated 1.6 and $3.5 \mathrm{~kb}$ mRNA levels in whole adrenals. 
In confirmation of results from Northern blot analysis, increases in the levels of immunoreactive StAR protein bands of 32 and $30 \mathrm{kDa}$ were observed $1 \mathrm{~h}$ after ACTH administration and remained elevated at $3 \mathrm{~h}$ and $5 \mathrm{~h}$. The increase in the level of a $29 \mathrm{kDa}$ immunoreactive band after ACTH administration was not statistically significant. This species was produced in smaller quantities than the other two. The same antibody used by Clark et al. (1997) to analyse StAR protein in MA-10 mouse Leydig tumor cells, specifically immunoprecipitated two proteins of $35 \cdot 5$ and $29 \cdot 1 \mathrm{kDa}$. This antibody was also successfully used for immunofluorescence histochemical studies and immuno-electron microscopy in rat adrenal (Ronen-Fuhrmann et al. 1998).

Although maximally increased after $1 \mathrm{~h}(1524 \%)$, hamster plasma cortisol levels decreased thereafter to values of $1056 \%$ and $504 \%$ after $3 \mathrm{~h}$ and $5 \mathrm{~h}$ of ACTH treatment respectively. At the present time we do not know why the plasma cortisol level was declining $5 \mathrm{~h}$ after $\mathrm{ACTH}$ administration while the adrenal StAR protein content was still maximally elevated. We can only speculate that, in the hamster adrenal in vivo, the quantity of StAR protein may not be the only rate-limiting component of steroidogenesis and that cholesterol availability, post-translational modifications, such as protease processing and phosphorylation which result in the formation of specific StAR species, may also be important.

In conclusion, in this study we have cloned the hamster adrenal StAR cDNA and we have shown that StAR protein is expressed in gonads and adrenals. We have also shown that administration of ACTH induces a rapid increase (within $1 \mathrm{~h}$ ) in adrenal StAR mRNA and protein, showing the importance of this component under acute $\mathrm{ACTH}$ stimulation in vivo.

\section{ACKNOWLEDGEMENTS}

We thank Andrée Lefebvre for her assistance. We also thank Dr Dennis Shapcott for reviewing this article. This work was supported by a grant from the Medical Research Council of Canada (MT10983), and the Heart and Stroke Foundation of Canada.

\section{REFERENCES}

Arakane F, King SR, Du Y, Kallen CB, Walsh LP, Watari H, Stocco DM \& Strauss JF 1997 Phosphorylation of steroidogenic acute regulatory protein (StAR) modulates its steroidogenic activity. Fournal of Biological Chemistry 272 32656-32662.
Clark BJ, Wells J, King SR \& Stocco DM 1994 The purification, cloning, and expression of a novel luteinizing hormone-induced mitochondrial protein in MA-10 mouse Leydig tumour cells. Characterization of the steroidogenic acute regulatory protein (StAR). Fournal of Biological Chemistry $26928314-28322$.

Clark BJ, Combs R, Hales KH, Hales DB \& Stocco DM 1997 Inhibition of transcription affects synthesis of steroidogenic acute regulatory protein and steroidogenesis in MA-10 mouse Leydig tumor cells. Endocrinology 138 4893-4901.

Cloutier M, Fleury A, Courtemanche J, Ducharme L, Mason JI \& LeHoux JG 1997 Characterization of the adrenal cytochrome P450C17 in hamster, a small animal model for the study of dehydroepiandrosterone. DNA and Cell Biology 16 357-368.

Crivello JF \& Jefcoate CR 1980 Intracellular movement of cholesterol in rat adrenal cells. Fournal of Biological Chemistry 255 8144-8151.

Elliott ME, Goodfriend TL, Ball DL \& Jefcoate CR 1997 Angiotensin-responsive adrenal glomerulosa cell proteins: characterization by protease mapping, species comparison, and specific angiotensin receptor antagonists. Endocrinology 138 2530-2536.

Epstein LF \& Orme-Johnson NR 1991 Regulation of steroid hormone biosynthesis: identification of precursors of a phosphoprotein targeted to the mitochondrion in stimulated rat adrenal cortex cells. Fournal of Biological Chemistry 266 19739-19745.

Fleury A, Cloutier M, Ducharme L, Lefebvre A, LeHoux J \& LeHoux JG 1996 Adrenocorticotropin regulates the level of the steroidogenic acute regulatory (StAR) protein $\mathrm{mRNA}$ in hamster adrenals. Endocrine Research 22 515-520.

Gradi A, Tangwai R, McBride HM, Chu LL, Shore GC \& Pelletier J 1995 The human steroidogenic acute regulatory (StAR) gene is expressed in the urogenital system and encodes a mitochondrial polypeptide. Biochimica et Biophysica Acta 1258 228-233.

Hartung S, Rust W, Balvers M \& Ivell R 1995 Molecular cloning and in vivo expression of the bovine steroidogenic acute regulatory protein. Biochemical and Biophysical Research Communications 215 646-653.

Hendrick JP, Hodges PE \& Rosenberg LE 1989 Survey of amino-terminal proteolytic cleavage sites in mitochondrial precursor proteins: leader peptides cleaved by two matrix proteases share a three-amino acid motif. Proceedings of the National Academy of Sciences of the USA $\mathbf{8 6}$ 4056-4060.

Jefcoate CR, DiBartolomeis MJ, Williams C \& McNamara BC 1987 ACTH regulation of cholesterol movement in isolated adrenal cells. Fournal of Steroid Biochemistry 27 721-729.

Juengel JL, Meberg BM, Turzillo AM \& Niswender GD 1995 Hormonal regulation of messenger ribonucleic acid encoding steroidogenic acute regulatory protein in ovine corpora lutea. Endocrinology 136 5423-5429.

Kim YC, Ariyoshi N, Artemenko I, Elliott ME, Bhattacharyya KK \& Jefcoate CR 1997 Cytochrome P450 scc in rat adrenal cells mediated by regulation of the steroidogenic acute regulatory protein. Steroids 62 10-20.

Krueger RJ \& Orme-Johnson NR 1983 Acute adrenocorticotropic hormone stimulation of adrenal corticosteroidogenesis. Fournal of Biological Chemistry 258 10159-10167.

Kyte J \& Doolittle RF 1982 A simple method for displaying the hydropathic character of a protein. Fournal of Molecular Biology 157 105-132.

Laemmli UK 1970 Cleavage of structural proteins during the assembly of the head of bacteriophage T4. Nature 227 680-685. 
Lee HK, Ahn RS, Kwon HB \& Soh J 1997 Nucleotide sequence of rat steroidogenic acute regulatory protein complementary DNA. Biochemical and Biophysical Research Communications 230 528-532.

LeHoux JG, Mason JI \& Ducharme L 1992 In vivo effects of adrenocorticotropin on hamster adrenal steroidogenic enzymes. Endocrinology 131 1874-1882.

LeHoux JG, Bernard H, Ducharme L, Lefebvre A, Shapcott D, Tremblay A \& Véronneau S $1996 a$ The regulation of the formation of glucocorticoids and mineralocorticoids in vivo. In Advances in Molecular and Cell Biology, vol 14, pp 149-201. Ed CR Jefcoate. London, England: JAI Press Inc.

LeHoux JG, Lefebvre A, Ducharme L, LeHoux J, Martel D \& Brière N $1996 b$ Some effects of a low sodium intake on the expression of $\mathrm{P} 450$ aldosterone synthase in the hamster adrenal cortex: immunoblotting, immunofluorescent and immuno-gold electron microscopic studies. Fournal of Endocrinology 149 341-349.

Miyamoto K, Mizutani T \& Sonoda Y 1997 In GenBank, Accession Number AB001349.

Pilon N, Daneau I, Brisson C, Éthier JF, Lussier JG \& Silversides DW 1997 Porcine and bovine steroidogenic acute regulatory protein (StAR) gene expression during gestation. Endocrinology 138 1085-1091.

Pon LA \& Orme-Johnson NR 1986 Acute stimulation of steroidogenesis in corpus luteum and adrenal cortex by peptide hormones. Rapid induction of a similar protein in both tissues. Fournal of Biological Chemistry 261 6594-6599.

Pon LA, Hartigan JA \& Orme-Johnson NR 1986 Acute ACTH regulation of adrenal corticosteroid biosynthesis. Rapid accumulation of a phosphoprotein. Fournal of Biological Chemistry 261 13309-13316.

Ronen-Fuhrmann T, Timberg R, King SR, Hales KH, Hales DB, Stocco DM \& Orly J 1998 Spatio-temporal expression patterns of steroidogenic acute regulatory protein (StAR) during follicular development in the rat ovary. Endocrinology 139 303-315.

Sandhoff TW \& McLean MP 1996 Hormonal regulation of steroidogenic acute regulatory (StAR) protein messenger ribonucleic acid expression in the rat ovary. Endocrine 4 259-267.

Selvaraj N, Israeli D \& Amsterdam A 1996 Partial sequencing of the rat steroidogenic acute regulatory protein message from immortalized granulosa cells: regulation by gonadotropins and isoproterenol. Molecular and Cellular Endocrinology 123 171-177.

Stocco DM \& Clark BJ 1996 Regulation of the acute production of steroids in steroidogenic cells. Endocrine Reviews 17 221-244.

Sugawara T, Holt JA, Driscoll D, Strauss III JF, Lin D, Miller WL, Patterson D, Clancy KP, Hart IM, Clark BJ \& Stocco DM 1995 a Human steroidogenic acute regulatory protein: functional activity in COS-1 cells, tissue-specific expression, and mapping of the structural gene to $8 \mathrm{p} 11 \cdot 2$ and a pseudogene to chromosome 13. Proceedings of the National Academy of Sciences of the USA 92 4778-4782.

Sugawara T, Lin D, Holt JA, Martin KO, Javitt NB, Miller WL \& Strauss III JF $1995 b$ Structure of the human steroidogenic acute regulatory protein (StAR) gene: StAR stimulates mitochondrial cholesterol 27-hydroxylase activity. Biochemistry 34 12506-12512.

Tremblay A, Waterman MR, Parker KL \& LeHoux JG 1991 Regulation of rat adrenal messenger RNA and protein levels for cytochrome P-450 s and adrenodoxin by dietary sodium depletion or potassium intake. Fournal of Biological Chemistry $2662245-2251$.

REVISED MANUSCRIPT RECEIVED 16 March 1998 